www.jmscr.igmpublication.org

Impact Factor 5.84

Index Copernicus Value: 71.58

ISSN (e)-2347-176x ISSN (p) 2455-0450

crossref DOI:_https://dx.doi.org/10.18535/jmscr/v5i10.25

Journal Of Medical Science And Clinical Research

\title{
The Prognostic Value of Luminal Subtypes of Breast Cancer and their Impact on the Patient's Outcome
}

\author{
Authors \\ Ahmed Abdel-Latif Abdel Kader, Tarek Abdel Halim El Fayoumi, \\ Mohammed Ahmed El-Sayed Saqr, Ahmed Tarek Fouad Awad \\ Department of surgery, Faculty of Medicine, University of Alexandria
}

\begin{abstract}
Background: Breast cancer is the major cause of death by cancer among females in developing countries. Although the overall breast cancer incidence rate in the developed countries is double that seen in developing countries, the mortality rates from the disease are generally similar. However, survival following breast cancer tends to be poorer in developing countries, this is attributed to late diagnosis and limited access to standard treatment. One of the challenges in treating the disease is addressing the biological heterogeneity evident in the presence of several histologic and molecular subtypes. ${ }^{(1-4)}$

Despite advances, about $20 \%$ to $30 \%$ of patients with early breast cancers will experience distantmetastatic relapse. ${ }^{(5)}$ Risk of recurrence is inhanced by the stage at initial presentation and the underlying molecular biology of the tumor. Nodal ,Tumor size, , grade, lympho-vascular and perineural invasion, and estrogen receptor (ER) ${ }^{(6)}$ and human epidermal growth factor receptor $2(\text { HER2 })^{(7)}$ status are all major risk factors for relapse.

The response of breast cancer patients to hormonal therapy is currently guided by the expression of two steroid hormonal receptors $(H R)$ : estrogen receptor- $\alpha(E R-\alpha)$, progesterone receptor $(P R)$ and proliferation marker Ki-67. Expression of PR, in fact, has been reported to confer good prognosis to breast cancer patients. ${ }^{(8)}$ Another molecular marker that is increasingly being examined in breast cancer for therapeutic potential as well as a prognostic indicator is the human epidermal growth factor receptor type 2 (Her-2/neu) oncoprotein. ${ }^{(9-11)}$ Although several subtype classifications have been developed, the different classifications generally agree on four subtypes (luminal A, luminal B, HER2-enriched and basal-like). ${ }^{(12)}$

Aim of the study: The aim of this study is to assess the hormonal receptors and molecular subtypes for their impact on management in breast cancer patients.

Patients:This study was carried out retrospectively on 400 patients presented to Surgical oncology unit; Alexandria Main University Hospital, Medical and Surgical Oncology units; Gamal Abdel-Nasser Health Insurance Hos-pital was obtained within 3 years from January 2010 to January 2013.

Subjects and Methods: The patients data were collectedfromSurgical oncology unit; Alexandria Main University Hospital, Medical and Surgical Oncology units; Gamal Abdel-Nasser Health Insurance Hos-pital within 3 years from January 2010 to January 2013 and filtered into flow sheets.

Results: The age was varying between 32.0 - 86.0 years with a mean age of $55.27 \pm 9.24$ years.Luminal $A$ subtype was found to be the most frequent type presenting $74.3 \%$ of patients followed by Luminal B $(12.3 \%)$, Triple-ve (10.5\%) and Her 2 type, the least common, presenting $3.0 \%$ of patients. Infiltrating duct carcinoma
\end{abstract}


(NOS) (IDC) was the most commonly diagnosed histopathological type presenting $93.8 \%$ of cases.There was no history of recurrence of the primary tumor in $80.3 \%$ of cases, $8.7 \%$ of cases presented with loco-regional recurrence (LRR) and $11.0 \%$ of cases presented with distant recurrence within four years after excision of the primary tumor. The Triple -ve group had the highest incidence of recurrence with $48.0 \%$ and $16.0 \%$ of cases with loco-regional recurrence and distant recurrence respectively, followed by Luminal B and Luminal A subtypes. Her2-enriched subtype showed no distant recurrence among the group patients.

Conclusion: Luminal A subtype is the most frequent biological subtype and Her2 type is the least common. Triple -ve group has the highest incidence of recurrence with $48.0 \%$ and $16.0 \%$ of cases with loco-regional recurrence and distant recurrence respectively, followed by Luminal A and B subtypes and Her 2 enriched subtype showed no distant recurrence among the group patients.

\section{Introduction}

Breast cancer is the major cause of death by cancer among females in developing countries. Although the overall breast cancer incidence rate in the developed countries is double that seen in developing countries, the mortality rates from the disease are generally similar. However, survival following breast cancer tends to be poorer in developing countries, this is attributed to late diagnosis and limited access to standard treatment. One of the challenges in treating the disease is addressing the biological heterogeneity evident in the presence of several histologic and molecular subtypes. $^{(1-4)}$

\section{Prognostic factors of breast cancer:}

\section{Axillary Lymph-nodal Status}

The presence or absence of axillary lymph node involvement is considered as the most significant prognostic indicator for patients with breast cancer. Furthermore, there is a direct relationship between the number of involved axillary nodes and the risk for distant recurrence ${ }^{(13,14)}$. The 5year survival for patients with node-negative disease (N0) is about $82.8 \%$ compared with $73 \%$ for 1 - 3 positive nodes (N1), $45.7 \%$ for $4-9$ positive nodes ( 2 ), and $28.4 \%$ for $\geq 10$ positive nodes $(\mathrm{N} 3)^{(15)}$. These data show that the risk of recurrence is significant with lymph node positive disease to require adjuvant systemic therapy.

\section{Age at Diagnosis}

Two relatively large trials have demonstrated that patients younger than 35 years of age with breast cancer have worse prognosis than older ones, even after adjustment for other prognostic factors. ${ }^{(16,17)}$
Moreover, very young women have higher incidence of advanced stages at time of diagnosis and poorer 5-year survival than older premenopausal patients. ${ }^{(18-20)}$

\section{Tumor Size}

Tumor size correlates with the presence and number of involved axillary lymph nodes.It is also an independent prognostic factor, with distant recurrence rates increasing with larger tumor size. Rosen et al. examined the relationship between the size of the tumor and 20-year recurrence-free survival and found that there is a significant association, with a 20-year recurrence-free survival of $88 \%$ for tumors $\leq 1 \mathrm{~cm}, 72 \%$ for tumors $1.1 \mathrm{~cm}$ to $3 \mathrm{~cm}$, and $59 \%$ for tumors between $3.1 \mathrm{~cm}$ and $5 \mathrm{~cm}{ }^{(21)}$. For patients with negative lymph nodes, tumor size is the most important prognostic factor and is routinely used to make adjuvant treatment decisions.

\section{Tumor Type/Grade}

The pathological characteristics of the tumor have prognostic significance. Certain subtypes such as tubular, mucinous, and medullary have a more favorable prognosis than unspecified breast cancer (22-24). The most widely used grading system is the Scarff-Bloom-Richardson (SBR) classification (25). Degree of differentiation, mitotic index and pleomorphism are scored from 1 to 3 and the scores from each category are totaled.

\section{Lympho-vascular and peri-neural Invasion}

Lymphatic vessel and vascular invasion (LVI) has been demonstrated to have prognostic importance for the risk of local and distant recurrence. At 20 years of follow-up, Rosen et al. noted a correlation between lympho-vascular invasion and 
the risk of recurrence. The recurrence rate for women with LVI-positive stage I disease was $38 \%$ compared with $22 \%$ for those with LVI-negative disease. Lympho-vascular invasion does have prognostic significance and is used essentially to make decisions for nodal-negative patients with borderline tumor sizes. ${ }^{(26)}$

\section{ER/PR Status}

The presence of estrogen and progesterone receptors in an invasive breast carcinoma have both prognostic and predictive significance. Its prognostic effect is difficult to evaluate in that it must be assessed in the absence of adjuvant tamoxifen. ${ }^{(27)}$

\section{Ki67 (New prognostic factor)}

Ki-67 protein (also known as MKI67) is a cellular proliferation marker. The Ki-67 expression as detected by immunohistochemistry is one of the most reliable indicators of the proliferative status of cancer cells ${ }^{(28)}$. In 2011, Ki-67 was considered as one of the factors affecting molecular subtypes (29). Ki-67 expression is closely associated with the growth and invasion of breast cancer: Ki-67positive breast cancers are more active in growth, more aggressive in invasion, and more metastatic. Cheang et al. ${ }^{(30)}$ integrated Ki-67 expression as a prognostic factor into molecular typing, and their results showed that Luminal B breast cancer patients (ER and/or PR positive, HER-2 positive, $\geq 14 \% \mathrm{Ki}-67$ positive cells) with positive axillary lymph nodes had a poorer 10-year recurrence free survival rate $(64 \%)$ and a poorer overall survival rate $(74 \%)$ when compared with Luminal A breast cancer patients (ER and/or PR positive, HER2 negative, $<\quad 14 \% \quad \mathrm{Ki}-67$ positive cells). Furthermore, two meta-analyses showed that Ki67 is an important factor affecting the recurrence of early breast cancer and the survival of breast cancer patients ${ }^{(31,32)}$. The prognostic value of $\mathrm{Ki}$ 67 has been associated with poorer prognosis in breast cancer patients with negative axillary lymph nodes in most studies ${ }^{(33-35)}$.

\section{Patients and Methods}

This retrospective study was carried out on 400 patients presented to Surgical Oncology unit; Alexandria Main University Hospital, Medical and Surgical Oncology units; Gamal AbdelNasser Health Insurance Hospital.

The patient's data was randomly obtained from patient's oncology files within 3 years from January 2010 to January 2013 or as back as we need to reach the number of patients wanted.

The data was be filtered and collected into flow sheets including the personal data,history of presenting symptoms, reproductive history, history of oral contraceptive pill use, past medical history, clinical examination, investigations, treatment received and follow up.

The patients were classified according to the hormonal receptor status into the four biological subtypes of breast cancer (luminal A, luminal B, HER2-enriched and triple negative).

\section{Results}

According to age, the age of the patients was varying between 32.0 and 86.0 years with a mean age of $55.27 \pm 9.24$ years with no statistically significant difference between groups.

According to the distribution of biological types among the studied cases, comparison between various biological types shows that Luminal A type presents $74.3 \%$, Luminal B type $12.3 \%$, Her2 type $3.0 \%$ and Triple -ve type $10.5 \%$ of cases. (Figure 1)

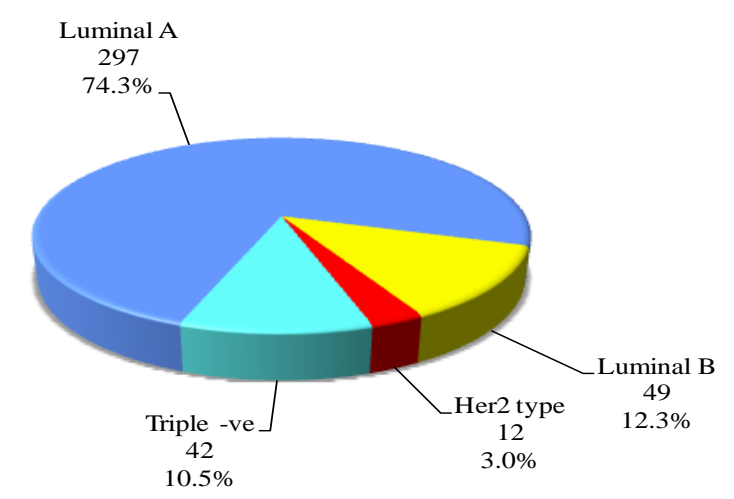

Figure (1): Distribution of the studied cases according to biological type 
According to history of oral contraceptive pills, $18 \%$ of patients gave history of OCP intake and $82 \%$ gave no history of OCP intake with no statistically significant difference between groups.(Table 1)

Infiltrating duct carcinoma (IDC) (NOS) is the most common type presenting $93.8 \%$ of cases.IDC (NOS) was histo-pathologically diagnosed in 93.8\% of cases while invasive lobular carcinoma accounts for $4.5 \%$, mixed ductal and lobular carcinoma accounts for $1.0 \%$ and mucoid adenocarcinoma accounts for $0.7 \%$ of total cases with no statistically significant difference. (Table 1)

As regards to the size of the tumors in our study, T2 tumors $(2-5 \mathrm{~cm}$ in size) were the commonest presenting tumors in all molecular subtypes where they represented $60.5 \%$ of total number of patients, T1 (less than $2 \mathrm{~cm}$ ) represented $24.0 \%$ of patients and $\mathrm{T} 3$ (more than $5 \mathrm{~cm}$ ) represented $15.5 \%$ of total number of patients which is statistically significant ( $\mathrm{p}$ value $=0.003$ ). (Figure 2 )

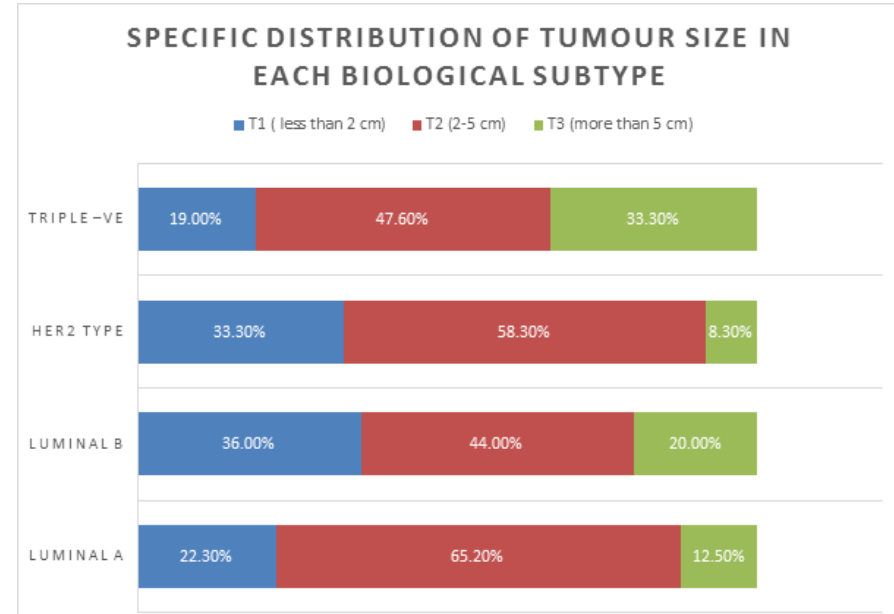

Figure (2): Comparison between groups according to tumor size in each biological subtype

Axillary LN dissection of the 400 study cases showed that $24.3 \%$ of cases had negative axillary LN spread (N0), $31.3 \%$ with $1-3$ positive LNs (N1), 33\% with 4-9 positive LNs (N2) and $11.5 \%$ with 10 or more positive LNs (N3) with no statistically significant difference. (Table 1)
Also, the study showed that 335 cases $(83.8 \%)$ had no distant metastasis (M0) while 65 cases $(16.3 \%)$ had distant metastasis (M1) at the time of presentation; $40.5 \%$ of Triple $-\mathrm{ve}, 24.0 \%$ of Luminal B and $12.2 \%$ of Luminal A patients had M1 tumors while Her2 enriched group reported no primary distant metastasis among the study cases which is statistically significant $(\mathrm{p}=0.000)$. (Table 1)

As regards to staging in our study, $9.75 \%$ of cases found to be as stage I, $34 \%$ as stage II, $40 \%$ as stage III and $16.25 \%$ as stage IV ( $p$ value $=0.002$ ). (Table 1)

According to recurrence, 66 patients reported the occurrence of recurrence representing $19.7 \%$ of total number of study patients; with 29 cases of loco-regional recurrence and 37 cases with distant relapse; while 269 patients had no relapse till the time of study representing $80.3 \%$ of total study patients which is statistically significant $(\mathrm{p}=0.000)$. (Figure 3)

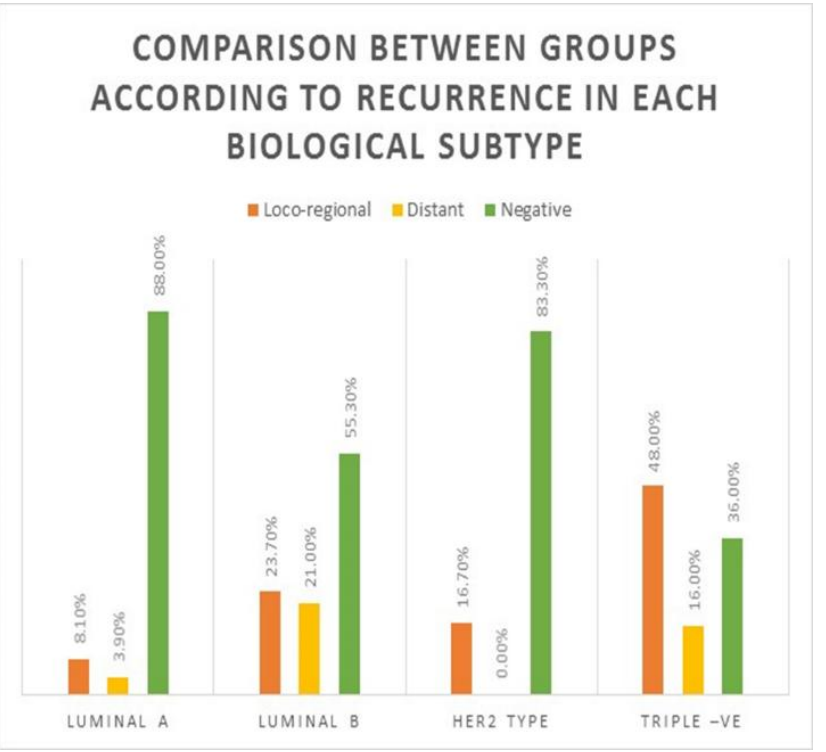

Figure (3) Comparison between groups according to recurrence in each biological subtype 
Table (1): Comparisone between different biological subtype groups

\begin{tabular}{|c|c|c|c|c|c|}
\hline & & Luminal A & Luminal B & Her2-enriched & Triple -ve \\
\hline \multicolumn{2}{|c|}{ Mean age } & $55.67 \pm 8.93$ & $55.47 \pm 10.58$ & $53.50 \pm 10.93$ & $52.69 \pm 9.06$ \\
\hline \multirow[t]{2}{*}{ History of OCPs } & Positive & $13.9 \%$ & $32.0 \%$ & $25.0 \%$ & $28.6 \%$ \\
\hline & Negative & $86.1 \%$ & $68.0 \%$ & $75.0 \%$ & $71.4 \%$ \\
\hline \multicolumn{2}{|l|}{ Incidence } & 74.3 & 12.3 & 3.0 & 10.5 \\
\hline \multirow[t]{4}{*}{ Histopathological type } & IDC (NOS) & $93.5 \%$ & $96.0 \%$ & $100.0 \%$ & $93.8 \%$ \\
\hline & Invasive lobular & $4.4 \%$ & $4.0 \%$ & $0.0 \%$ & $4.5 \%$ \\
\hline & Mixed IDC \& lobular & $1.4 \%$ & $0.0 \%$ & $0.0 \%$ & $0.0 \%$ \\
\hline & $\begin{array}{c}\text { Mucoid } \\
\text { adenocarcinoma }\end{array}$ & $0.6 \%$ & $0.0 \%$ & $0.0 \%$ & $0.7 \%$ \\
\hline \multirow[t]{3}{*}{ Tumor size (in cm) } & T1 (less than $2 \mathrm{~cm}$ ) & $22.3 \%$ & $36.0 \%$ & $33.3 \%$ & $19.0 \%$ \\
\hline & $\mathrm{T} 2(2-5 \mathrm{~cm})$ & $65.2 \%$ & $44.0 \%$ & $58.3 \%$ & $47.6 \%$ \\
\hline & T3 (more than $5 \mathrm{~cm}$ ) & $12.5 \%$ & $20.0 \%$ & $8.3 \%$ & $33.3 \%$ \\
\hline \multirow[t]{4}{*}{ Lymph-node metastasis } & N0 (No LN metastasis) & $26.4 \%$ & $18.0 \%$ & $16.7 \%$ & $19.0 \%$ \\
\hline & N1 (1-3 LN metastasis) & $30.1 \%$ & $36.0 \%$ & $33.3 \%$ & $33.3 \%$ \\
\hline & N2 (4-9 LN metastasis) & $32.4 \%$ & $32.0 \%$ & $25.0 \%$ & $40.5 \%$ \\
\hline & N3 ( $\geq 10$ LN metastasis) & $11.1 \%$ & $14.0 \%$ & $25.0 \%$ & $7.1 \%$ \\
\hline \multirow[t]{2}{*}{ Distant metastasis (M) } & $\begin{array}{c}\text { M0 (No distant } \\
\text { metastasis) }\end{array}$ & $87.8 \%$ & $76.0 \%$ & $100.0 \%$ & $59.5 \%$ \\
\hline & M1 (Distant metastasis) & $12.2 \%$ & $24.0 \%$ & $0.0 \%$ & $40.5 \%$ \\
\hline \multirow[t]{4}{*}{ Stage } & $\bar{I}$ & $11.1 \%$ & $10.0 \%$ & $0.0 \%$ & $2.4 \%$ \\
\hline & II & $34.8 \%$ & $30.0 \%$ & $50.0 \%$ & $28.5 \%$ \\
\hline & III & $41.9 \%$ & $36.0 \%$ & $50.0 \%$ & $28.6 \%$ \\
\hline & IV & $12.2 \%$ & $24.0 \%$ & $0.0 \%$ & $40.5 \%$ \\
\hline \multirow[t]{3}{*}{ Recurrence } & Loco-regional & $8.1 \%$ & $23.7 \%$ & $16.7 \%$ & $48.0 \%$ \\
\hline & Distant & $3.9 \%$ & $21.0 \%$ & $0.0 \%$ & $16.0 \%$ \\
\hline & Negative & $88.0 \%$ & $55.3 \%$ & $83.3 \%$ & $36.0 \%$ \\
\hline
\end{tabular}

\section{Discussion}

Molecular classification of breast cancer is an important prognostic factor. ${ }^{(36)}$ Gene expression profiling has a significant impact on our understanding of breast cancer biology. During the last 15 years, four molecular subtypes of breast cancer were identified; Luminal A, Luminal B, HER-2 enriched and Triple negative (Basal like). These subtypes have shown significant differences in terms of their incidence, risk factors, prognosis and treatment sensitivity. ${ }^{(37-41)}$ The hormonal receptor status of the thestudy patients showed that Luminal A subtype was found to be the most frequent type presenting $74.3 \%$ of patients followed by Luminal B (12.3\%), Triple -ve (10.5\%) and Her2 type, the least common, presenting $3.0 \%$ of patients.Several studies including study by Cadoo KA et al, Park $S$ et al and Haibe-Kains $B$ et al. reported that luminal $\mathrm{A} / \mathrm{B}$ tumors were the most frequently observed subtype $(56 \%-63 \%)$, followed by the basal-like $(19 \%-27 \%)$ and HER2-enriched (13\%-15\%) subtypes.(42-44) This also reported by Sørlie $\mathrm{T}$ et al and Calza $\mathrm{S}$ et al. They showed that Luminal A subtype is the most commonly diagnosed subtype and the HER2-enriched subtype is the least common one. ${ }^{(45-46)}$

As regards to the histopathological type in our study, Infiltrating duct carcinoma (NOS) (IDC) was the most commonly diagnosed histopathological type presenting $93.8 \%$ of cases with no statistically significant difference.Studies by Carter CL et al, Rao C et al and Chakrabarti S et al also reported that IDC was the most commonly diagnosed histopathological type of breast cancer. ${ }^{(47-49)}$

As regards to the size of the tumors in our study, $\mathrm{T} 2$ tumors $(2-5 \mathrm{~cm}$ in size) were the commonest presenting tumors in all molecular subtypes where they represented $60.5 \%$ of total number of patients, T1 (less than $2 \mathrm{~cm}$ ) represented $24.0 \%$ of patients and $\mathrm{T} 3$ (more than $5 \mathrm{~cm}$ ) represented $15.5 \%$ of total number of patients. Rakha EA et al conducted a study on 2,219 cases. The study showed that 412 cases $(18.6 \%)$ were $\mathrm{T} 1$, about 790 were T2 (35.6\%), and 1,017 cases $(45.6 \%)$ were T3. (139) Similar findings were observed by 
Carter CL et al, Liu ZF et al and Widodo et al. $(47,50-51)$

As regards to distant metastasis at the time of presentation in our study, $16.3 \%$ of patients diagnosed with distant metastasis (M1), distributed in the different groups as follow; $40.5 \%$ of Triple $-\mathrm{ve}, 24.0 \%$ of Luminal B and $12.2 \%$ of Luminal A patients had M1 tumors while Her2 enriched group reported no primary distant metastasis among the study cases which is statistically significant ( $\mathrm{p}$ value $=0.000$ ). In the study of Kast K et al between 2006 and 2011, metastatic disease was mostly found in Her2enriched $(29.4 \%)$ and triple negative breast cancer (20.2\%) among 2284 breast cancer cases, while fewer cases with metastatic disease were found in luminal A breast cancer compared to all other subtypes. It also observed that Her2enriched subtype presented with primary and secondary metastatic disease in the same time, whereas triple negative breast cancer more likely developed metastatic disease as a secondary event, while the luminal A subtype cases with primary metastatic disease were diagnosed more frequently than cases with secondary metastases. ${ }^{(52)}$ Similar results were reported by Sanpaolo P et al, Savci-Heijink CD et al and GarcíaFernández A et al. ${ }^{(53-55)}$

As regards to staging in our study, $9.75 \%$ of cases found to be as stage I, $34 \%$ as stage II, $40 \%$ as stage III and $16.25 \%$ as stage IV ( $p$ value $=0.002$ ). In a study by Jung HA et al, a total of 1145 patients were diagnosed with breast cancer and received curative surgery. Of these, $463(40.4 \%)$ patients were stage I, and $682(59.6 \%)$ were stage II or III. ${ }^{(56)}$

As regards to recurrence in our study, $80.3 \%$ of cases gave no history of recurrence of the primary tumor, $8.7 \%$ of cases presented with loco-regional recurrence (LRR) and $11.0 \%$ of cases presented with distant recurrence within four years after excision of the primary tumor ( $p$ value $=0.000$ ). The Triple -ve group had the highest incidence of recurrence with $48.0 \%$ and $16.0 \%$ of cases with loco-regional recurrence and distant recurrence respectively, followed by Luminal B with $23.7 \%$ of LRR and $21.0 \%$ of distant metastasis. Luminal A group also showed LRR in $8.1 \%$ of cases and distant recurrence in $3.9 \%$ of cases. Her2 type group showed no distant recurrence among the group patients. Lowery AJ et al. showed that Patients with luminal subtype tumors $(\mathrm{A} / \mathrm{B})$ had a lower risk of recurrence than both triple-negative and HER2/neu-overexpressing tumors. ${ }^{(57)}$ NofechMozes S et al, de Ruijter TC et al and Rhee $\mathrm{J}$ et al found that patients with triple-negative breast cancer (TNBC) suffer from poor prognosis compared to other breast cancer subtypes, TNBC develop earlier in life, and consequently more often in pre-menopausal women. ${ }^{(58-60)}$ Tobin NP et al. study showed that basal-like and HER2enriched subtypes were associated with the worst survival outcome and the highest incidence of relapse compared with the luminal A subtype. Overall, $32 \%$ of the metastases were HER2enriched, $25 \%$ basal-like, $10 \%$ luminal $\mathrm{A}$ and $28 \%$ luminal B. ${ }^{(61)}$ Oakman $\mathrm{C}$ et al and Rubovszky $\mathrm{G}$ et al also reported that Triple negative breast cancer (TNBC) accounts for approximately $15 \%$ of breast cancer cases. TNBC occurs in younger women and is marked by high rates of visceral and CNS metastases, relapse and early death. ${ }^{(62-63)}$

\section{Conclusions}

Luminal A subtype is the most frequent biological subtype and Her2 type is the least common. Triple -ve group has the highest incidence of recurrence with $28.6 \%$ and $9.5 \%$ of cases with loco-regional recurrence and distant recurrence respectively, followed by Luminal A and B subtypes and Her2 enriched subtype showed no distant recurrence among the group patients.

\section{Refrences}

1. Jemal A, Bray F, Center MM, Ferlay J, Ward E, Forman D. Global cancer statistics. CA Cancer J Clin 2011;61:6990. 
2. Ferlay J, Shin HR, Bray F, Forman D, Mathers C, Parkin DM. Estimates of world-wide burden of cancer in 2008: GLOBOCAN 2008. In: GLOBOCAN 2008. Int J Cancer 2010 15;127(12):2893917.

3. Harford JB, Otero IV, Anderson BO, Cazap E, Gradishar WJ, Gralow JR, et al. Problem solving for breast health care delivery in low and middle resource countries (LMCs): consensus statement from the Breast Health Global Initiative. Breast 2011;20(Suppl 2):S20-9.

4. Rodrigues AD, Bustamante-Teixeira MT. Breast cancer and cervical cancer mortality trends in a medium-sized city in Southern Brazil, 1980-2006. Cad SaudePublica 2011;27(2):241-8.

5. Early Breast Cancer Trialists' Collaborative Group (EBCTCG). Effects of chemotherapy and hormonal therapy for early breast cancer on recurrence and 15year survival: an overview of the randomised trials. Lancet 2005;365(9472):1687-717.

6. Alanko A, Heinonen E, Scheinin T, Tolppanen EM, Vihko R. Significance of estrogen and progesterone receptors, disease-free interval, and site of first metastasis on survival of breast cancer patients. Cancer 1985;56(7):1696-700.

7. Chia S, Norris B, Speers C, Cheang M, Gilks B, Gown AM, et al. Human epidermal growth factor receptor 2 overexpression as a prognostic factor in a large tissue microarray series of nodenegative breast cancers. J ClinOncol 2008; 26(35):5697-704.

8. Anderson BO, Yip CH, Smith RA, Shyyan R, Sener SF, Eniu A, et al. Guideline implementation for breast healthcare in low-income and middleincome countries: overview of the Breast Health Global
Initiative Global Summit. Cancer 2008;113(Suppl 8):2221-43

9. Ghosh R, Narasanna A, Wang SE, Liu S, Chakrabarty A, Balko JM, et al. Trastuzumab has preferential activity against breast cancers driven by HER2 homodimers. Cancer Res 2011;71(5):1871-82

10. Konecny G, Pauletti G, Pegram M, Untch M, Dandekar S, Aguilar Z, et al. Quantitative association between HER$2 /$ neu and steroid hormone receptors in hormone receptor-positive primary breast cancer. J Natl Cancer Inst 2003;95(2):14253.

11. James R, Thriveni K, Krishnamoorthy L, Deshmane V, Bapsy PP, Ramaswamy G. Clinical outcome of adjuvant endocrine treatment according to Her-2/neu status in breast cancer. Indian $\mathrm{J}$ Med Res 2011;133(1):70-5.

12. Piccat-Gebhart MJ. New developments in hormone receptor-positive disease. Oncologist 2011;16(Suppl 1):40-50.

13. Saez RA, McGuire WL, Clark GM. Prognostic factors in breast cancer. SeminSurgOncol 1989;5:102-10.

14. Nemoto T, Natarajan N, Bedwani R, Vana J, Murphy GP. Breast cancer in the medial half; results of the 1978 national survey of the American College of Surgeons. Cancer 1983;51:1333-8.

15. Fisher B, Bauer M, Wickerham DL, Redmond CK, Fisher ER, Cruz AB, et al. Relation of the number of positive axillary nodes to the prognosis of patients with primary breast cancer. An NSABP update. Cancer 1983;52:1551-7.

16. Nixon AJ, Neuberg D, Hayes DF, Gelman R, Connolly JL, Schnitt S,et al. Relationship of patient age to pathologic features of the tumor and prognosis for patients with stage I or II breast cancer. J ClinOncol 1994;12(5):888-94. 
17. Albain KS, Allred DC, Clark GM. Breast cancer outcome and predictors of outcome: are there age differentials? J Natl Cancer Inst Mongr 1994;16:35-42.

18. Anders CK, Hsu DS, Broadwater G, Acharya CR, Foekens JA, Zhang Y,et al. Young age at diagnosis correlates with worse prognosis and defines a subset of breast cancers with shared patterns of gene expression. J ClinOncol 2008;26(20): 3324-30.

19. Hartley MC, McKinley BP, Rogers EA, Kalbaugh CA, Messich HS, Blackhurst DW, et al. Differential expression of prognostic factors and effect on survival in young $(<$ or $=40)$ breast cancer patients: a case-control study. Am Surg 2006;72(12): 1189-94.

20. Holli K, Isola J. Effect of age on the survival of breast cancer patients. Eur J Cancer 1997;33(3):425-8.

21. Rosen PP, Groshen S, Kinne DW, Norton L. Factors influencing prognosis in nodenegative breast carcinoma: analysis of 767 T1N0M0/T2N0M0 patients with long-term follow-up. J ClinOncol 1993;11:2090-100.

22. Carstens PH, Greenberg RA, Francis D, Lyon H. Tubular carcinoma of the breast. A long term follow-up. Histopathol 1985;99:271-80.

23. Clayton F. Pure mucinous carcinomas of the breast: morphologic features and prognostic correlates. Hum Pathol 1986;17:34-8.

24. Ridolfi RL, Rosen PP, Port A, Kinne D, Miké V. Medullary carcinoma of the breast: a clinicopathologic study with a ten year follow-up. Cancer 1977;40:1365-85.

25. Bloom HJ, Richardson WW. Histological grading and prognosis in breast cancer: a study of 1409 cases of which 359 have been followed for 15 years. Br J Cancer 1957;11:359-77.
26. Rosen PP, Groshen S, Saigo PE, Kinne DW, Hellman S. Pathological prognostic factors in stage I (T1N0M0) and stage II (T1N1M0) breast carcinoma: a study of 644 patients with median follow-up of 18 years. J ClinOncol 1989; 7:1239-51.

27. Fisher B, Redmond C, Fisher ER, Caplan R. Relative worth of estrogen or progesterone receptor and pathologic characteristics of differentiation as indicators of prognosis in node-negative breast cancer patients. Findings from National Surgical Adjuvant Breast and Bowel Project Protocol B-06. J ClinOncol 1988;6:1076-87.

28. Goldhirsch A, Ingle JN, Gelber RD, Coates AS, Thürlimann B, Senn HJ, et al. Thresholds for therapies: highlights of the St Gallen International Expert Consensus on the primary therapy of early breast cancer 2009. Ann Oncol 2009; 20(8):1319-29.

29. Cheang MC, Chia SK, Voduc D, Gao D, Leung S, Snider J, et al. Ki67 index, HER2 status, and prognosis of patients with luminal B breast cancer. J Natl Cancer Inst 2009; 101(10):736-50.

30. Goldhirsch A, Wood WC, Coates AS, Gelber RD, Thürlimann B, Senn HJ, et al. Strategies for subtypes-dealing with the diversity of breast cancer: highlights of the St. Gallen International Expert Consensus on the Primary Therapy of Early Breast Cancer 2011. Ann Oncol 2011;22(8):173647.

31. de Azambuja E, Cardoso F, de Castro G Jr, Colozza M, Mano MS, Durbecq V, et al. $\mathrm{Ki}-67$ as prognostic marker in early breast cancer: a meta-analysis of published studies involving 12,155 patients. $\mathrm{Br} \mathrm{J}$ Cancer 2007; 96(10):1504-13.

32. Stuart-Harris R, Caldas C, Pinder SE, Pharoah P. Proliferation markers and survival in early breast cancer: a 
systematic review and meta-analysis of 85 studies in 32,825 patients. Breast 2008;17(4):323-34.

33. Urruticoechea A, Smith IE, Dowsett M. Proliferation marker Ki-67 in early breast cancer. J ClinOncol 2005; 23(28):7212-20.

34. Neri A, Marrelli D, Pedrazzani C, Caruso S, De Stefano A, Mariani F, et al. Prognostic relevance of proliferative activity evaluated by Mib-1 immunostaining in node negative breast cancer. Eur J SurgOncol 2008; 34(12):1299-303.

35. Jalava $\mathrm{P}$, Kuopio $\mathrm{T}$, Juntti-Patinen $\mathrm{L}$, Kotkansalo T, Kronqvist P, Collan Y. Ki67 immunohistochemistry: a valuable marker in prognostication but with a risk of misclassification: proliferation subgroups formed based on Ki67 immunoreactivity and standardized mitotic index. Histopathology 2006; 48(6):674-82.

36. Su Y, Zheng Y, Zheng W, Gu K, Chen Z, Li G, et al. Distinct distribution and prognostic significance of molecular subtypes of breast cancer in Chinese women: a population-based cohort study. BMC Cancer 2011;11:292.

37. Perou CM, Sorlie T, Eisen MB, van de Rijn M, Jeffrey SS, Rees CA, et al. Molecular portraits of human breast tumours. Nature 2000;406(6797):747-52.

38. Prat A, Perou CM. Deconstructing the molecular portraits of breast cancer. MolOncol 2011;5(1):5-23.

39. Prat A, Parker JS, Fan C, Perou CM. PAM50 assay and the three-gene model for identifying the major and clinically relevant molecular subtypes of breast cancer. Breast Cancer Res Treat 2012;135(1):301-6.

40. Prat A, Parker JS, Karginova O, Fan C, Livasy C, Herschkowitz JI, et al. Phenotypic and molecular characterization of the claudin-low intrinsic subtype of breast cancer. Breast Cancer Res 2010;12(5):R68.

41. Cancer Genome Atlas Network. Comprehensive molecular portraits of human breast tumours. Nature 2012;490(7418):61-70.

42. Cadoo KA, Fornier MN, Morris PG. Biological subtypes of breast cancer: current concepts and implications for recurrence patterns. Q J Nucl Med Mol Imaging 2013;57(4):312-21.

43. Park S, Koo JS, Kim MS, Park HS, Lee JS, Lee JS, et al. Characteristics and outcomes according to molecular subtypes of breast cancer as classified by a panel of four biomarkers using immunohistochemistry. Breast 2012;21(1):50-7.

44. Haibe-Kains B, Desmedt C, Loi S, Culhane AC, Bontempi G, Quackenbush J, et al. A three-gene model to robustly identify breast cancer molecular subtypes. J Natl Cancer Inst 2012;104(4):311-25.

45. Sørlie T, Perou CM, Tibshirani R, Aas T, Geisler S, Johnsen $\mathrm{H}$, et al. Gene expression patterns of breast carcinomas distinguish tumor subclasses with clinical implications. Proc Natl AcadSci U S A 2001;98(19):10869-74.

46. Calza S, Hall P, Auer G, Bjöhle J, Klaar S, Kronenwett $\mathrm{U}$, et al. Intrinsic molecular signature of breast cancer in a populationbased cohort of 412 patients. Breast Cancer Res 2006;8(4):R34.

47. Carter CL, Allen C, Henson DE. Relation of tumor size, lymph node status, and survival in 24,740 breast cancer cases. Cancer 1989;63(1):181-7.

48. Rao C, Shetty J, Kishan Prasad HL. Morphological profile and receptor status in breast carcinoma: an institutional study. J Cancer Res Ther 2013;9(1):44-9.

49. Chakrabarti S, Karmakar R, Barui G, Maity PK, Bandyopadhyay A, Roy A. Prevalence of known prognostic factors in 
female breast carcinoma including oestrogen receptor, progesterone receptor and Her-2/neu status--a study in a tertiary care centre. J Indian Med Assoc 2012;110(12):876-9.

50. Liu ZF, Chen C, Yao XL, Sun SR. Clinicopathological characteristics and prognosis of different molecular types of breast cancer. Zhonghua Yi XueZaZhi 2016;96(22):1733-7.

51. Widodo I, Dwianingsih EK, Triningsih E, Utoro T. Clinicopathological features of indonesian breast cancers with different molecular subtypes. Asian Pac J Cancer Prev 2014;15(15):6109-13.

52. Kast K, Link T, Friedrich K, Petzold A, Niedostatek A, Schoffer O, et al. Impact of breast cancer subtypes and patterns of metastasis on outcome. Breast Cancer Res Treat 2015;150(3):621-9.

53. Sanpaolo P, Barbieri V, Genovesi D. Prognostic value of breast cancer subtypes on breast cancer specific survival, distant metastases and local relapse rates in conservatively managed early stage breast cancer: a retrospective clinical study. Eur J SurgOncol 2011;37(10):876-82.

54. Savci-Heijink CD, Halfwerk H, Hooijer GK, Horlings HM, Wesseling J, van de Vijver MJ. Retrospective analysis of metastatic behaviour of breast cancer subtypes. Breast Cancer Res Treat 2015;150(3):547-57.

55. GarcíaFernández A, Giménez N, Fraile M, González S, Chabrera C, Torras M, et al. Survival and clinicopathological characteristics of breast cancer patient according to different tumour subtypes as determined by hormone receptor and Her2 immunohistochemistry. a single institution survey spanning 1998 to 2010. Breast 2012;21(3):366-73.

56. Jung HA, Park YH, Kim M, Kim S, Chang WJ, Choi MK, et al. Prognostic relevance of biological subtype overrides that of TNM staging in breast cancer: discordance between stage and biology. TumourBiol 2015;36(2):1073-9.

57. Lowery AJ, Kell MR, Glynn RW, Kerin MJ, Sweeney KJ. Locoregional recurrence after breast cancer surgery: a systematic review by receptor phenotype. Breast Cancer Res Treat 2012;133(3):831-41.

58. Nofech-Mozes S, Trudeau M, Kahn HK, Dent R, Rawlinson E, Sun P, et al. Patterns of recurrence in the basal and non-basal subtypes of triple-negative breast cancers. Breast Cancer Res Treat 2009;118(1):1317.

59. De Ruijter TC, Veeck J, de Hoon JP, van Engeland M, Tjan-Heijnen VC. Characteristics of triple-negative breast cancer. J Cancer Res ClinOncol 2011;137(2):183-92.

60. Rhee J, Han SW, Oh DY, Kim JH, Im SA, Han W, et al. The clinicopathologic characteristics and prognostic significance of triple-negativity in node-negative breast cancer. BMC Cancer 2008;8:307.

61. Tobin NP, Harrell JC, Lövrot J, EgyhaziBrage S, FrostvikStolt M, Carlsson L, et al. Molecular subtype and tumor characteristics of breast cancer metastases as assessed by gene expression significantly influence patient post-relapse survival. Ann Oncol 2015;26(1):81-8

62. Oakman C, Viale G, Di Leo A. Management of triple negative breast cancer. Breast 2010;19(5):312-21.

63. Rubovszky G, Udvarhelyi N, Horváth Z, Láng I, Kásler M. Triple-negative breast carcinoma--rewiev of current literature. MagyOnkol 2010;54(4):325-35. 